\title{
SUSCEPTIBILITY PROFILE OF CANDIDA SPP. ISOLATED FROM HUMANS AND DOGS WITH STOMATITIS TO THE ESSENTIAL OIL OF THIMUS VULGARIS
}

\author{
ŽIVKOVIĆ R*, PERIĆ MIRJANA*, ARSIĆ-ARSENIJEVIĆ VALENTINA** MARTINOVIĆ Ž", \\ PEKMEZOVIĆ MARINA**, STOJIĆ Ž ${ }^{*}$, RAIČKOVIĆ VANJA* and ĐURIŠIĆ S* \\ University of Belgrade, Faculty of Stomatology, Serbia \\ University of Belgrade, Faculty of Medicine, Serbia
}

\section{(Received $7^{\text {th }}$ June 2013)}

Candida spp. form a part of human and animal oral cavity flora. However Candida spp. is the main cause of dental related stomatitis in humans and stomatitis in dogs. Stomatitis treatment implies the use of azoles and polyenes to which yeasts build up resistance. The research is directed to the use of natural compounds such as essential oils.

The aim of this paper is to define the antifungal activity of thyme oil on 15 clinical strains of Candida spp., isolated from humans and dogs and to determine if there is a difference in susceptibility between human and dog isolates.

Sampling in patients with stomatitis was done by swabbing the denture or oral mucosa swab while sampling in dogs was done by swabbing the oral cavity mucosa after stomatitis has been diagnosed. In order to investigate the antifungal activity of thyme oil in vitro, microdilution method was used.

Thyme oil expressed antifungal effects on all investigated strains. Also, our data show that the values of minimum fungicide concentration (MFC) and minimum inhibitory concentration (MIC) are lower in human strains. Explanation is that in most cases, stomatitis in humans is asymptomatic and thus not treated, so Candida strains have not developed resistance. On the other hand, stomatitis in dogs is followed by a marked clinical picture and treated is by antimicotics (mostly by azoles), therefore resistant Candida strains are more likely to occur.

Key words: Candida, dogs, essential oil, stomatitis, Thymus vulgaris 


\section{INTRODUCTION}

Yeasts of genus Candida are residential microorganisms which very often can be found in both human (Carvalhinho, 2012) and animal oral cavity. Apart from the oral cavity, Candida is present in some other human and animal moist areas such as: skin, inner ear, conjunctival canal, mouth, digestive system and perianal area. Candida yeasts along with other microorganisms are microbes of healthy living beings, but in specific conditions they can cause opportunistic infections (Cleff et al., 2005).

Candida albicans (C. albicans) is the main etiological factor of oral candidiasis in humans and other small animals. Apart from $C$. albicans, other kinds of oral yeasts may be included in various pathogenic processes. In the available literature, the following are found: C. glabrata, C. krusei, C. tropicalis, C. dubliniensis, C. parapsilosis in humans or C. parapsilosis, and C. guilliermondi and C.tropicalis in dogs (Moreti et al., 2006; Cleff et al., 2007; Pozzatti, 2007; Yurayart et al., 2011).

There are different clinical manifestations of oropharyngeal candidiasis in humans, including pseudomembranous candidiasis (trush) and erythematous forms such as denture related stomatitis, which is often recurrent (Cannon et al., 1995). Wearing prosthetic appliances is commonly associated with denture stomatitis, which is characterized by inflamed mucosa covered by denture, more often under the upper denture (Wilson, 1998). Patients with denture related stomatitis may complain of burning sensation, discomfort, or bad taste. However patients very often do not have any symptoms. There are many pre-dilutional factors that influence denture stomatitis, including age of denture, denture cleanliness, continuous constant denture wearing, denture trauma which appears as a consequence of wearing dentures, smoking, dietary factors, $\mathrm{pH}$ of denture plaque (Soysa et al., 2004, 2006). Denture stomatitis is a disease of fungal and bacterial origin, and C. albicans is most frequently isolated yeast from the patients' oral cavities (Baena-Monroy et al., 2005). Denture is more often a reservoir of microorganisms from which they can spread and cause diseses to other organs.

Stomatitis in dogs is characterized by erythematous oral mucous membrane which is ulcerous and covered with pseudo membranes, with halitosis and hypersalvation (McKcever and Klausener, 1986).

Opportunistic infections in dogs develop as a consequence of deteriorating defense mechanisms, immunosuppression and prolonged antibiotic treatment (Moreti et al., 2006; Cleff et al., 2007; Ong et al., 2010; Yurayart et al., 2011). Different Candida species are very important pathogenic factors in small animals and they are linked to urinary infections, (Ozawa et al., 2005) skin lesions (Moretti et al., 2004), otitis and systematic infections (Brown et al., 2005).

Today candidiosis is a problem of public health due to resistance to conventional antifungal medicines and there are some reports on relapsing disease especially in immunocompromised patients (Sanglard and Kvota, 2002; Kolombo and Guimaraes, 2003; Pozzatti et al., 2010). 
In general, oral $C$. albicans isolates have high levels of susceptibilities to a range of antifungal agents (Kuriyama et al., 2005), but some studies have shown high levels of azoles resistance in C. albicans strains isolated from the throat and mouth (Paniaqua et al., 2002; Manifredi et al., 2006). Owing to their antibacterial effects, essential oils are the alternative for antibiotics in the pharmaceutical industry (Bakkali, 2008). The increase of $C$. albicans resistance to antifungal medicines encourages the research of new therapeutic alternatives such as essential oils (Giordani et al., 2004; Cavaleiro et al., 2006).

Studies on essential oils have a goal to examine active compounds with a wide spectrum of effects, low toxicity and low prices (Rochette et al., 2003). Treatment of fungal infection in veterinary medicine is limited to conventional polyenes and triazoles. Additionally, these medicines have adverse effects and relatively high prices, especially when they are used for animals (Sanglard, 2002; Mondelo et al., 2003; Pressler et al., 2003; Rochette et al., 2003; Lukman et al., 2007).

The aim of this study is to:

1. determine antifungal activity (minimum inhibitory concentration - MIC and minimum fungicide concentration - MFC)

2. determine if there is a difference in susceptibility profile of Candida spp. isolated in both humans and dogs

\section{MATERIAL AND METHODS}

\section{Essential oils}

In the research, the essential thyme oil used (Citychem, Belgrade, Serbia), was obtained by water vapour distillation under of Thymus vulgaris flowers. The percentage of particular components of thyme oil is given in Table 1.

Table 1. Components of thyme oil

\begin{tabular}{|c|c|}
\hline Substance & $\%$ \\
\hline Thymol & 46.0 \\
\hline$\rho$-cymene & 27.5 \\
\hline$\gamma$-terpinene & 9.0 \\
\hline Linalool & 6.5 \\
\hline Carvarcrol & 2.5 \\
\hline$\beta$-myrcene & 2.4 \\
\hline Terpinen-4-ol & 1.5 \\
\hline
\end{tabular}

\section{Fungal strains}

The study has included the research of 15 clinical isolates of Candida spp. isolated in seven patients with diagnosed dental related stomatitis (5 C.albicans, 
2 C.glabrata, 2 C.krusei and 1 C. tropicalis) and five dogs with stomatitis (3 C.albicans, 1 C.parapsilosis and 1 C. krusei).

The sampling in patients was done by swabs taken from their dentures (in patients with dental stomatitis) or by oral mucosa swabs. The sampling in dogs was done by mucosa swabs of the oral cavity when stomatitis has been diagnosed.

Swabs were transported to the microbiological laboratory in a period no longer than 30 minutes from the moment of sampling. Material was seeded on CHROMAgar Candida plates (CHROMagar, Paris, France) and incubated at $37^{\circ} \mathrm{C}$ for 48 hours. The identification of Candida strains was done according to the specific appearance of the colonies as defined by the manufacturer.

In vitro antifungal activities of thymes oil

Susceptibility of strains to thyme oil has been investigated by the microdilution method according to the standardized protocol by The European Committee on Antimicrobial Susceptibility Testing - EUCAST (EUCAST). Serial oil dilutions were prepared in RPMI 1640 with $2 \%$ of glucose, in the concentration range $0.1=$ $16 \mu \mathrm{LL} \mathrm{m}^{-1}$.

Before testing, 15 Candida isolates, together with two reference strains ( $C$. albicans ATCC 24433 and C. krusei ATCC 6258) were cultivated on Sabouraud dextrose agar plates (Oxoid, Basingstoke, United Kingdom) at $37^{\circ} \mathrm{C}$ during 24 hours. Yeast suspension has been prepared in sterile $0.9 \% \mathrm{NaCl}$ and adjusted to 0.5 McFarland standard of turbidity (which fits the size of inoculums of $\left.1-5 \times 10^{6} \mathrm{CFU} / \mathrm{mL}\right)$.

Each chamber of the microtitration plates was inoculated by adding $100 \mu \mathrm{L}$ of yeast suspension and $100 \mu \mathrm{L}$ of corresponding concentration of thyme oil. The test has also included three controls: positive control/growth control (fungi in PRMI 1640 without thyme oil), negative control (fungi in solution $2 \mu \mathrm{g} / \mathrm{mL}$ of amphotericine B) and sterility control (only RPMI 1640 without yeast suspensions).

Microtitration plates were incubated at $37^{\circ} \mathrm{C}$. The results have been read visually after 24 and 48 hours on the basis of chamber's content turbidity. MIC is defined as the lowest concentration of solution which causes a significant decrease in turbidity comparing to the positive control.

Determination of Minimum fungicide concentration (MFC) is done by seeding $20 \mu \mathrm{l}$ from all clear wells on SDA incubated at $37^{\circ} \mathrm{C}$ for $24-48$ hours.

\section{RESULTS}

Essential thyme oil has manifested antifungal effects to all tested strains. The susceptibility results presented as MIC and MFC values are shown in Table 2 for Candida strains isolated from humans and Table 3 for strains isolated from dogs.

Strains of the species C.albicans have shown the greatest susceptibility to thyme oil, while between other Candida species difference in MIC/MFC values has not been noticed. 
Table 2. The results of Candida spp. susceptibility isolated from humans

\begin{tabular}{|c|c|c|c|}
\hline Strain number & Species & $\mathrm{MIC}\left(\mu \mathrm{mL}^{-1}\right)$ & $\mathrm{MFC}\left(\mu \mathrm{LL}^{-1}\right)$ \\
\hline $36 \mathrm{~A}$ & C.albicans & 0.5 & 1 \\
\hline $62 \mathrm{~A}$ & C.albicans & 0.2 & 0.5 \\
\hline $80 \mathrm{~A}$ & C.albicans & 0.2 & 0.5 \\
\hline $82 \mathrm{~A}$ & C.albicans & 0.2 & 0.5 \\
\hline $87 \mathrm{~A}$ & C.albicans & 0.2 & 0.5 \\
\hline $90 \mathrm{~T}$ & C.tropicalis & 0.5 & 1 \\
\hline $49 \mathrm{G}$ & C.glabrata & 0.5 & 1 \\
\hline $60 \mathrm{G}$ & C.glabarata & 0.5 & 1 \\
\hline $33 \mathrm{~K}$ & C. krusei & 0.5 & 1 \\
\hline $43 \mathrm{~K}$ & C.krusei & 0.5 & 1 \\
\hline
\end{tabular}

Table 3. Susceptibility results of Candida spp. isolated from dogs

\begin{tabular}{|c|c|c|c|}
\hline Strain number & Species & $\mathrm{MIC}(\mu \mathrm{L} \mathrm{mL}-1)$ & $\mathrm{MFC}\left(\mu \mathrm{LL}^{-1}\right)$ \\
\hline $\mathrm{A} 12$ & C.albicans & 5.0 & 5.0 \\
\hline $\mathrm{A} 2$ & C.albicans & 2.5 & 5.0 \\
\hline $\mathrm{A} 8$ & C.albicans & 2.5 & 5.0 \\
\hline $\mathrm{K} 4$ & C.krusei & 5.0 & 10 \\
\hline $\mathrm{P} 15$ & C.parapsilosis & 1.25 & 5.0 \\
\hline
\end{tabular}

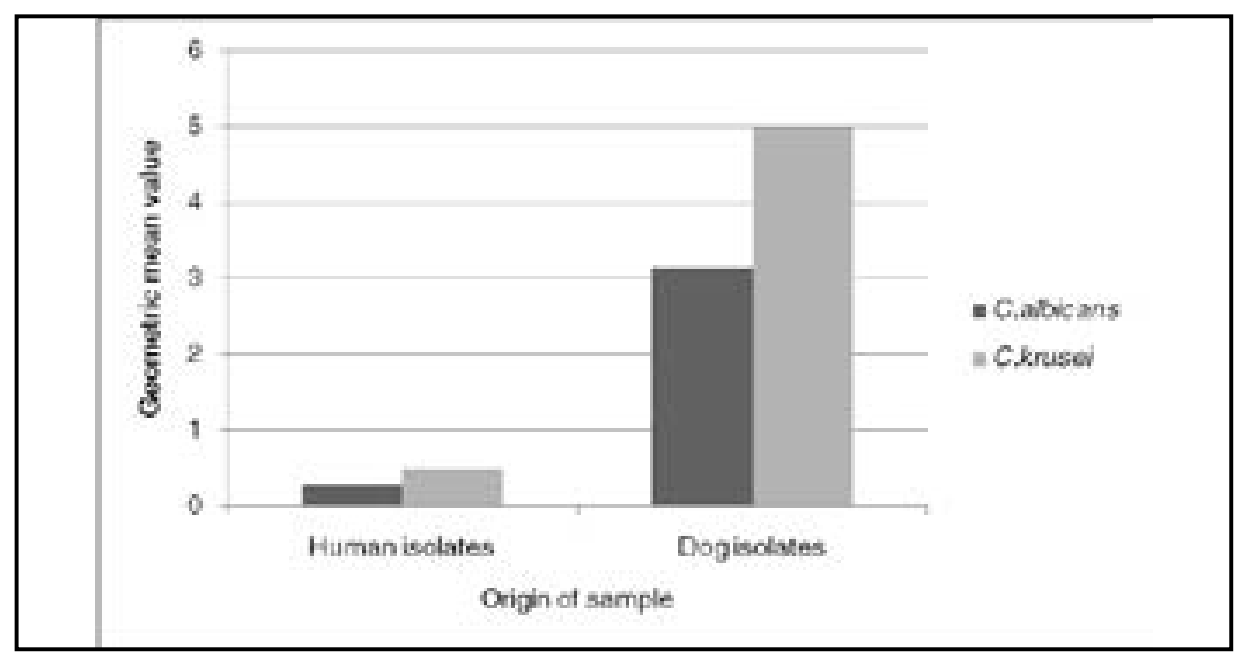

Figure 1. Comparison of $\mathrm{Gm}$ values for human and dog isolates 
On the basis of our results it may be concluded that Candida spp. isolated from humans shows higher susceptibility to thyme oil compared to Candida spp. isolated from dogs. Comparison of geometric mean (GM) values for human and dog isolates is given in Figure 1.

\section{DISCUSSION}

The effect of essential oils and their main components on Candida spp. have been confirmed in in vitro and in vivo studies ( Giordani et al., 2004; Tamperi et al., 2005; Duarte et al., 2005; Pinto et al., 2006; He et al., 2007; Palmeira- de Oliveira et al., 2009). Their activity can usually be presumed on the basis of their chemical content. Essential oils have antifungal activity since they contain high content of phenol. Thymus spp. is very rich in phenol (thymol). Thymus zygis is classified as a fungicide due to its powerful effect on C.albicans ( Pina - Vaz, 2004). Various studies have shown that thyme oils manifest the highest antifungal activity compared to other essential oils (Omran, 2009).

Scanning by SEM, Braga and del Sasso (2008) have shown that the effect of thymol causes the change of susceptibility of the cell membrane, degradation of cellular wall, leaking of cell content, coagulation and cell lysis (Bakkali et al., 2008; Palmeira de Olivera et al., 2009). Concentrations below the MIC values significantly inhibited germ tube formation, an important virulence factor (Pina Vaz, 2004).

Hammer (1999) has also defined MIC of thyme oil for C.albicans from $0.03 \%$ $\left(0.3 \mu \mathrm{L} \mathrm{mL}^{-1}\right)$ by using the microdilution method. In this study the value was $0.02 \%$ $\left(0.2 \mu \mathrm{L} \mathrm{mL}^{-1)}\right.$ for human isolates of C.albicans.

In the study of Omran et al. (2010) where antifungal activity of thyme oil was investigated by disc diffusion method, MIC for Candida spp. was $2 \mathrm{mg} / \mathrm{mL}=0.02 \%$. C.albicans showed the highest susceptibility, followed by C.krusei and C.glabata (Omran et al., 2009). In our research, C.albicans strains also expressed the highest susceptibility. C. krusei is less susceptible to thyme oil and to other essential oils due to its cellular structure, as well as the intensified action of cell pumps which disturb the entrance of essential oils into the cell (Mondelo et al., 2003; Pozzatti, 2007).

Our study also demonstrated higher susceptibility of human Candida spp. comparing to the strains Candida spp. isolated from dogs, which could be explained in a way that dental related stomatitis in patients very often is not treated. Therefore, human strains of Candida spp. have not developed resistance. On the other hand, in dogs, stomatitis has been accompanied by a stronger clinical picture, and is treated by antimicotics (mostly azoles) therefore resistant profiles of Candida spp. are more likely to occur. 
Address for correspondence:

Živković Rade

School of dentistry, 11000 Belgrade

Dr Subotića 8

E-mail: radezivko@gmail.com

\section{REFERENCES}

1. Baena-Monroy T, Moreno-Maldonado V, Franco-Martinez F, Aldape-Barrios B, Quindos G, Sanchez-Vargas LO, 2005, Candida albicans, Staphylococcus aureus and Streptococcus mutans colonization in patients wearing dental prosthesis. Med Oral Patol Oral Cir Bucal 10(suppl 1), E27-E39.

2. Bakkali F, Averbeck S, Averbeck D, Idaomar M, 2008, Biological effects of essential oils-a review, Food Chem Toxicol, 46,446-75.

3. Braga PC, Culici M, Alfieri M, Dal Sasso M, 2008, Thymol inhibits Candida albicans biofilm formation and mature biofilm, Int $J$ Antimicrob Agents, 31,472-7.

4. Brown MR, Thompson CA, Mohamed FM, 2005, Systemic candidiasis in an apparently immunocompetent dog, J Vet Diag Invest, 17, 272-276.

5. Cavaleiro C, Pinto E, Gonc, alves MJ, Salgueiro L, 2006, Antifungal activity of Juniperus essential oils against dermatophyte, Aspergillus and Candida strains, J Appl Microbiol, $100,1333-8$.

6. Cannon RD, Holmes AR, Mason AB,Monk BC, 1995, Oral Candida: clearance, colonization, or candidiasis? J Dent Res, 74, 1152-61.

7. Carvalhinho S, Costa AM, Coelho AC, Martins E, Sampaio A, 2012, Susceptibilities of Candida albicans Mouth Isolates to Antifungal Agents, Essentials Oils and Mouth Rinses, Mycopathologia 174,69-76.

8. Cleff MB, Lima AP, Faria RO, Meinerz ARM, Antunes TA, Araújo FB et al., 2005, Isolation of Candida spp from vaginal microbiota of healthy canine females during estrous cycle, Braz J Microbioly, 36, 201-4.

9. Cleff MB, 2007, Infecção cutânea em cão por Candida albicans, Rev Vet Zootecn, 14, 2, 164-8.

10. Colombo AL, Guimares $T$, 2003, Epidemiologia das infecções hematogênicas por Candida spp. Rev Soc Bras Med Tropical, 36, 5, 599-607.

11. Duarte, M C, Figueira, GM, Sartoratto, A, Rehder, V L, Delarmelina C, 2005, Anti-Candida activity of Brazilian medicinal plants, $J$ Ethnopharmacoly, 97, 305-11.

12. Giordani R, Regli P, Kaloustian J, Mikail C, Abou L, Portugal H, 2004, Antifungal effect of various essential oils against Candida albicans. Potentiation of antifungal action of amphotericin B by essential oil from Thymus vulgaris, Phytother Res, 18, 990-5.

13. Hammer KA, Carson CF, Riley TV, 1999, Antimicrobial activity of essential oils and other plant extracts, J Appl Microbiol, 86, 6, 985-90.

14. He M, Du M, Fan M, Bian Z, 2007, In vitro activity of eugenol against Candida albicans biofilms. Mycopathologia, 163,137-43.

15. Kuriyama T, Williams DW, Bagg J, Coulter WA, Ready D, Lewis MA, 2005, In vitro susceptibility of oral Candida to seven antifungal agents, Oral Microbiol Immunol, 20, 349-53.

16. Luqman S, 2007, Potential of rosemary oil to be used in drug-resistant infections. Alter Therap Health Med, 13, 5, 54-9.

17. Lyon JP, da Costa SC, Totti VM, Munhoz MF, de Resende MA, 2006, Predisposing conditions for Candida spp. carriage in the oral cavity of denture wearers and individuals with natural teeth, Can J Microbiol, 52, 462-7.

18. Manfredi M, McCullough MJ, Polonelli L, Conti S, Al-Karaawi ZM, Vescovi $P$ et al., 2006, In vitro antifungal susceptibility to six antifungal agents of 229 Candida isolates from patients with diabetes mellitus. Oral Microbiol Immunol, 21, 177-82. 
19. McKeever PJ, Klausner JS, 1986, Plant awn, candidal, nocardial and necrotizing ulcerative stomatitis in the dog, J Am Anim Hosp Assoc, 22,17-24.

20. Mondelo $F, 2003$, In vitro and in vivo activity of tea tree oil against azole-susceptible and resistant human patogenic yeasts, $J$ Antimicrob Chemother, 51, 5, 1223-9.

21. Moretti A, Posteraro B, Boncio L, Mechelli L, Gasperis E, Agnetti F, 2004, Diffuse cutaneous candidiasis in a dog. Diagnosis by PCR-REA, Rev Iberoameric Micol, 21, 139-42.

22. Moretti $A, 2006$, Co-cutaneous infection in a dog: pcr-reverse identification of $C$. tropicalis on skin biopsy, J Mycol Medic, 16, 1, 30-6.

23. Omran MS, Esmailzadeh S, Rahmani Z, 2009, Comparison of anticandida activity of thyme, pennyroyal and lemon essential oils versus antifungal drugs against Candida species, Jundishapur J Microbiol, 2, 53-6.

24. Omran MS, Esmailzadeh S, Rahmani Z, 2010, Laboratory study of anticandidal activity of thyme, pennyroyal and lemon essential oils by micro dilution method, Jundishapur $J$ Microbiol.3, 4, 161-7.

25. Ozawa H, Okabayashi K, Kano R, Watari T, Watanabe S, Hasegawa A, 2005, Rapid identification of Candida tropicalis from canine cystitis, Mycopathologia, 160, 159-162.

26. Ong RK, Raisis AL, Swindells KL, 2010, Candida albicans peritonitis in a dog, J Vet Emerg Crit Care, 20, 1, 143-7.

27. Palmeira-de-Oliveira A, Salgueiro L, Palmeira-de-Oliveira R, Martinez-de-Oliveira J, Pina-Vaz C, et al., 2009, Anti-Candida Activity of Essential Oils, Mini-Rev Medic Chem, 9, 1292305.

28. Paniagua GLC, Monroy EP, Negrete EA, Vaca SP, 2002, Susceptibility to 5-Fluorocytosine, miconazole and amphotericin $B$ of Candida albicans strains isolated from the throat of non- AIDS patients. Rev Latinoam Microbiol, 44,65-8.

29. Pina-Vaz C, Goncalves Rodrigues A, Pinto E, Costa-de-Oliveira S, Tavares C, Salgueiro L, et al., 2004, Antifungal activity of Thymus oils and their major compounds, J Eur Acad Dermatol Venereol, 18, 73-8.

30. Pinto E, Pina-Vaz C, Salgueiro L, Goncalve MJ, Costa-de-Oliveira S, Cavaleiro C et al., 2006, Antifungal activity of the essential oil of Thymus pulegioides on Candida, Aspergillus and dermatophyte species, J Med Microbiol, 55, 1367-73.

31. Pozzatti $P, 2010$, Comparison of the susceptibilities of clinical isolates of Candida albicans and Candida dubliniensis to essential oils, Mycoses, 53, 1, 12-5.

32. Pressler BM , 2003, Candida spp. urinary tract infections in 13 dogs and seven cats: predisposing factors, treatment, and outcome, J Am Anim Hosp Assoc, 39, 3, 263-70.

33. Rochete F, Engelen M, Vanden Bossche $H, 2003$, Antifungal agents of use in animal healthpratical applications, $J$ Vet Pharmacol Ther, 26, 1, 31-53.

34. Sanglard D, Odds FC, 2002, Resistance of Candida species to antifungal agents: molecular mechanisms and clinical consequences, The Lancet Infect Dis, 2, 2, 3-85.

35. Soysa NS, Samaranayake LP, Ellepola AN, 2004, Cytotoxic drugs, radiotherapy and oral candidiasis, Oral Oncol , 40, 971-8.

36. Soysa NS, Samaranayake LP, Ellepola AN, 2006, Diabetes mellitus as a contributory factor in oral candidosis, Diabet Med, 23, 455-9.

37. Tampieri MP, Galuppi R, Macchioni F, Carelle MS, Falcioni L, Cioni PL et al., 2005, The inhibition of Candida albicans by selected essential oils and their major components, Mycopathologia, 159, 339-45.

38. Wilson J, 1998, The aetiology, diagnosis and management of denture stomatitis, $\mathrm{Br}$ Dent $\mathrm{J}$, $185,380-4$.

39. Yurayart $C, 2011$, Comparative analysis of the frequency, distribution and population sizes of yeasts associated with canine seborrheic dermatitis and healthy skin Vet Microbiol, $148,2-4,356-62$. 


\section{OSETLJIVOST SOJEVA CANDIDA SPP. IZOLOVANIH KOD ČOVEKA I PSA SA STOMATITISOM NA ETARSKO ULJE TIMIJANA}

\section{ŽIVKOVIĆ R, PERIĆ MIRJANA, ARSIĆ-ARSENIJEVIĆ VALENTINA, MARTINOVIĆ Ž, PEKMEZOVIĆ MARINA, STOJIĆ Ž, RAIČKOVIĆ VANJA i ĐURIŠIĆ S}

\section{SADRŽAJ}

Candida spp. je sastavni deo mikrobioma usne duplje čoveka i psa. Međutim Candida spp. predstavlja glavni uzročnik proteznog stomatitisa kod čoveka i stomatitisa kod psa. Terapija stomatitisa podrazumeva korišćenje azola i poliena na koje poslednjih godina gljivice razvijaju otpornost. Istrživanja se usmeravaju ka primeni prirodnih preparata kao što su etarska ulja. Cilj rada je utvrdi antifungalnu aktivnost ulja timijana na kliničke izolate Candida spp. čoveka i psa, i utvrdi da li postoji razlika u osetljivosti sojeva Candide spp. izolovanih kod čoveka i psa. Uzorkovanje kod pacijenata sa stomatitisom je vršeno brisom proteze ili brisom sluzokože. Kod pasa je uzrokovanje vršeno brisom sluzokože usne duplje kada je dijagnostikovan stomatitis. Zasejani sojevi su in vitro tretirani korišćenjem mikrodilucione metode da bi se utvrdilo da li ulje timijana deluje na kliničke izolate Candida spp. čoveka i psa. Rezultati pokazuju da su vrednosti minimalne fungicidne koncentracije (MFC) i minimalne inhibitorne koncentracije (MIC) manje kod čoveka. Stomatitis je kod ljudi najčešće je asimptomatski, pacijenti se ne podvrgavaju lečenju, pa sojevi Candida spp. nisu razvili rezistenciju na antifungicidne preparate. Kod pasa stomatitis je praćen burnijom kliničkom slikom, leči se antimikoticima (uglavnom azolima) pa je verovatnoća pojave rezistentnih sojeva Candida spp. veća. 